\title{
Artelogie
}

Recherche sur les arts, le patrimoine et la littérature de l'Amérique latine

$3 \mid 2012$

Image de la nation : art et nature au Chili

\section{Haciendo naturalezas: "Ecopoemas", "Escrito en el desierto", "Huacho"}

Martín Tironi y Christian Anwandter

\section{OpenEdition}

\section{Journals}

Edición electrónica

URL: https://journals.openedition.org/artelogie/7423

DOI: $10.4000 /$ artelogie.7423

ISSN: 2115-6395

Editor

Association ESCAL

Referencia electrónica

Martín Tironi y Christian Anwandter, «Haciendo naturalezas: "Ecopoemas", "Escrito en el desierto",

"Huacho"», Artelogie [En línea], 3 | 2012, Publicado el 12 septiembre 2012, consultado el 07 enero 2022. URL: http://journals.openedition.org/artelogie/7423 ; DOI: https://doi.org/10.4000/artelogie.7423

Este documento fue generado automáticamente el 7 enero 2022.

Association ESCAL 


\title{
Haciendo naturalezas: "Ecopoemas", "Escrito en el desierto", "Huacho"
}

\author{
Martín Tironi y Christian Anwandter
}

A Pedro Araya, por su ayuda indispensable para abordar la obra de Zurita, a la J002, al café Angora.

\section{Introducción}

1 En base a "Ecopoemas" (1983) de Nicanor Parra1, "Escrito en el desierto" (1994) de Raúl Zurita $^{2}$ y Huacho (2010), de Alejandro Fernández Almendras ${ }^{3}$, el presente artículo analiza los modos en que estos trabajos articulan y re-especifican la relación entre naturaleza y cultura. Tomando distancia de lecturas dualistas ${ }^{4}$, este texto propone una entrada pragmatista en la cual nociones como cultura, naturaleza y nación no son asumidas como causas autoevidentes, sino como efectos prácticos de un conjunto de mediaciones $^{5}$. Bajo esta perspectiva, tanto la naturaleza como la cultura no van a ser consideradas como cosas estables, y más bien las vamos a remitir a sus procesos de configuración y composición. Lo que interesa explorar no son las cosas en sí (como si estas obras hablaran de un mundo ya predefinido) sino las cosas en sus proceso de conformación. Por eso, y desde un punto de vista metodológico, ninguna distinción a priori se establecerá entre cultura y naturaleza ${ }^{6}$, para más bien restituir las técnicas y estrategias que estas obras ponen en práctica para hacer visibles esas nociones.

2 El objetivo es ofrecer una mirada no naturalizada de las entidades que configuran el universo de estas obras. Exploraremos esas zonas ontológicamente inciertas e inestables, tratando de no suscribir los contenidos en juego a formulaciones ya conocidas. Queremos examinar esos territorios híbridos, que no son ni naturales ni sociales, ni modernos ni pre-modernos, sino desplazamientos difusos, en proceso de solidificación. Expresar esta ambigüedad o incertidumbre ontológica es uno de los objetivos de este proyecto: no se trata de revelar una verdad ya dada detrás de estas obras, sino experimentar a través de ellas, como en un laboratorio, formas alternativas de comprender la articulación entre cultura y naturaleza en Chile. 
3 La opción de revisar críticamente la dicotomía cultura/naturaleza a través de estos trabajos responde a dos motivos fundamentalmente. En primer lugar, ofrece un material variado en cuanto a las diferentes mediaciones utilizadas: poesía, fotografía y cine. Entrecruzar estos lenguajes es una manera de poner a prueba la hipótesis sobre las prácticas y artefactos que participan en la creación de naturalezas.

Por otra parte, existe a nuestro juicio una dimensión cronológica que es interesante interrogar. Los tres trabajos que abordamos aquí comparten una preocupación por mostrar lo nacional y natural de Chile. Cada uno busca constituirse como una voz legítima acerca del orden socio-natural. Son registros comprometidos, pero sus trazos y énfasis cambian. Se observa una evolución en el tratamiento de la naturaleza: se pasa de una visión redentora, en que hay que salvarla o revela un futuro colectivo -con las figuras de Parra y Zurita- a una concepción minimalista con Huacho. Al delinear esta trayectoria en los modos de reformular la naturaleza no se pretende producir un "macro-relato histórico" sobre el tema, sino tan solo ponerlos en conversación.

La lectura que se hará de estos trabajos no es exhaustiva. No se intentará situarlos al interior del resto de la obra de cada autor ni tampoco hacer un análisis histórico de las obras. Es así como, en una primera parte ("Entidades puras") intentaremos reproducir, con algo de ironía, el discurso dualista naturaleza/cultura, tal como podría establecerse con respecto a estas obras, sirviéndonos de estas categorías como si fueran evidentes y perfectamente delimitadas. En una segunda parte ("El desborde de las transparencias"), habiendo experimentado las (im)posibilidades y limites de este discurso, intentaremos mostrar el continuo desborde del dualismo y la disolución constante de sus fronteras, prestando especial atención a las mediaciones, los dispositivos y soportes implicados en la producción y recepción de las obras analizadas. Para finalizar, y en la tercera parte del artículo ("Políticas de la naturaleza") abordamos las obras como configuradoras de categorías y realidades, subrayando el carácter político de las operaciones mediante las cuales emerge la naturaleza.

\section{Las entidades puras}

\section{Lenguaje y traducciones de la naturaleza}

Ya conocemos la naturaleza, aprendimos desde la infancia a reconocerla, identificarla, verla, experimentarla. Por eso resulta tan fácil detectar en las obras el tema de la naturaleza. En Poemas y antipoemas (1954), Parra aborda la naturaleza en textos como "Defensa del árbol" o "Se canta al mar". En estos poemas la naturaleza constituye un telón de fondo. También el Desierto de Atacama, en la obra de Zurita, es naturaleza. Encontramos además pampas, llanuras, playas y ríos. Toda una sección de Purgatorio se compone de poemas cuyos títulos son "El Desierto de Atacama" (de I a VI). En Anteparaíso (1982), una sección completa se compone de poemas llamados "Las Playas de Chile".

En los "Ecopoemas" de Parra, la naturaleza es nombrada como tal, como un todo:

EXPLOSIÓN DEMOGRÁFICA

SAQUEO DE LA NATURALEZA

COLAPSO DEL MEDIO AMBIENTE

vicios de la sociedad de consumo

que no podemos seguir tolerando:

¡hay que cambiarlo todo de raíz! 

ecopoema, un profesor dice despidiéndose de sus alumnos "ahora a defender los últimos cisnes de cuello negro / que van quedando en este país" ${ }^{8}$, no se necesita que alguien nos explique que los cisnes de cuello negro hacen parte de la naturaleza. Es una obviedad.

9 En el caso de la escritura en el desierto y también en el cielo de Zurita (incluida en forma de fotografía en La Vida nueva y Anteparaíso respectivamente), estamos claramente ante una escritura que se despliega en la naturaleza, esta vez como soporte para la escritura; una escritura que, como veremos, también abre esta naturaleza a la pregunta que la escritura pareciera hacerle. Eso sí: no hay pruebas sobre la pertenencia del cielo y del desierto a la naturaleza. Tampoco de los árboles y de los cisnes de cuello negro.

Figura 1: Fotografía de Lionel Cid, "Escrito en el cielo"

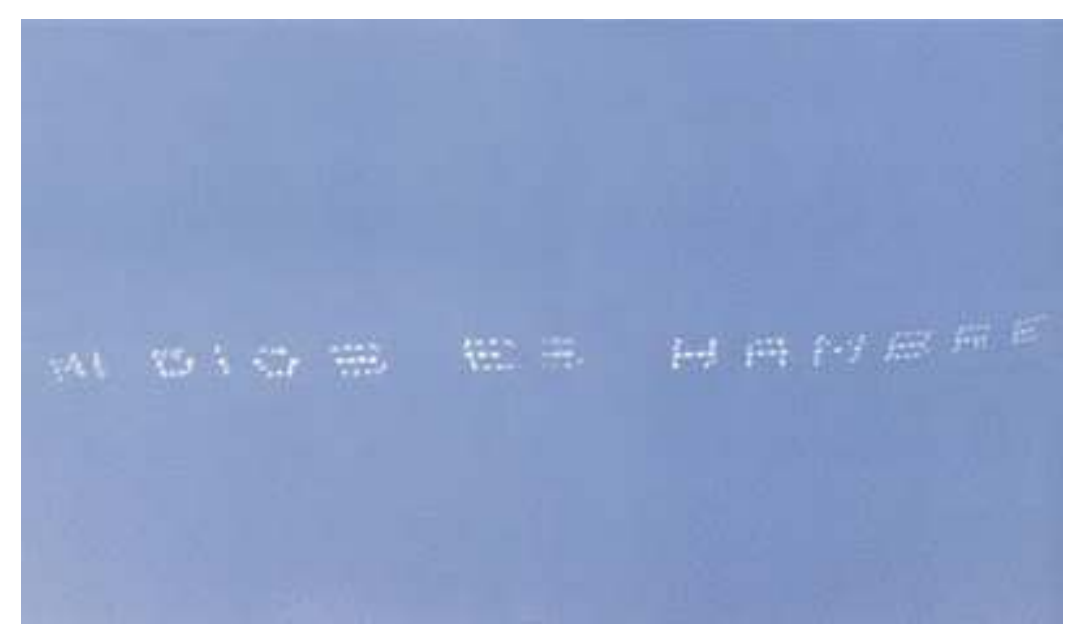

Anteparaíso, p.14-15

Figura 2: Vista aérea de "Escrito en el desierto", 56 km. al sur de Antofagasta

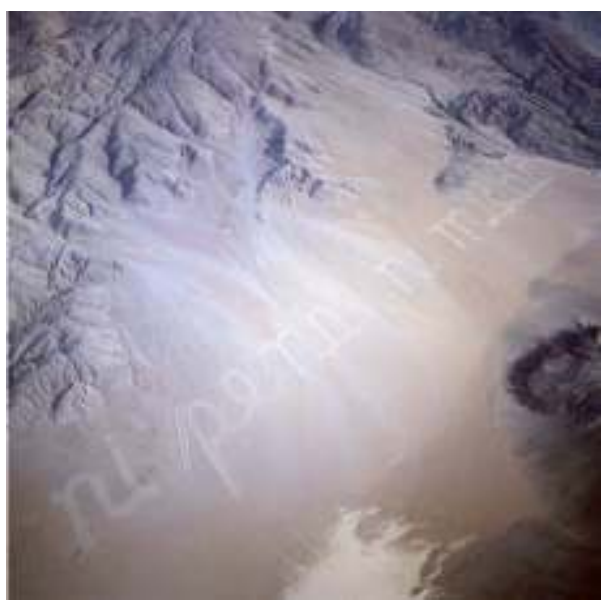

En Huacho también podemos encontrar esa evidencia de la naturaleza. La película se abre con el plano de un amanecer, donde alcanzamos a distinguir algunas siluetas de árboles y el canto matinal de pájaros y gallos. El encuadre perdura así algunos 
instantes, hasta que vemos encenderse la luz de una pequeña casa de madera, y una señora rezando al borde de su cama.

Figura 3: Señora rezando el rosario

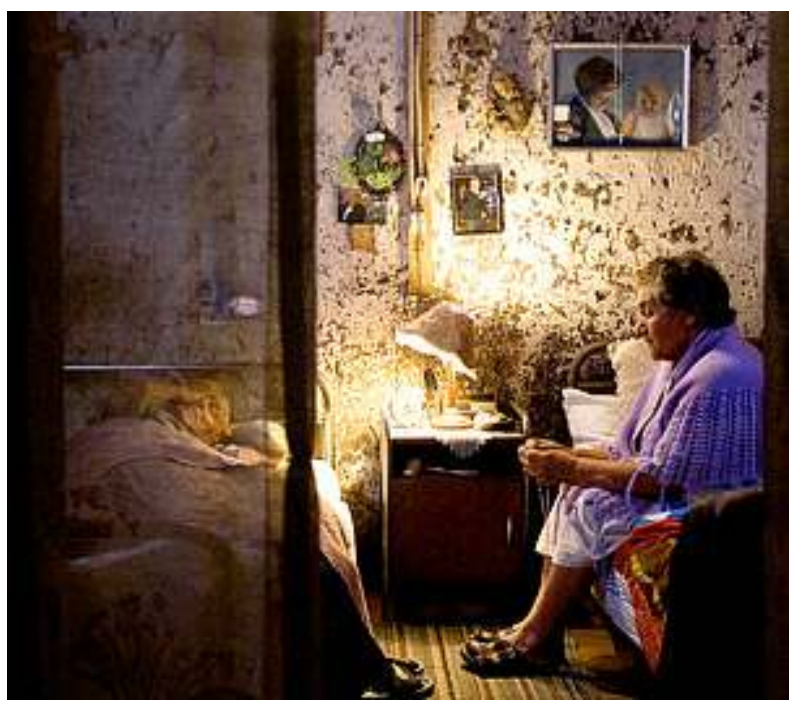

11 En los primeros minutos de metraje, Fernández Almendras establece el lugar de la película, que operará como telón de fondo: el campo chileno, sus prados y animales, la noche y los caminos de tierra. Pero la atmósfera, los sonidos y objetos que componen la secuencia inicial no solo delimitan un espacio geográfico, sino que también un territorio político: una zona en vías de urbanización, donde la luz eléctrica todavía llega intermitentemente y las aves se escuchan más que los automóviles.

\section{Tradiciones de la naturaleza}

La naturaleza de Huacho aparece fundamentalmente como escenario/soporte de un Chile anti-glamoroso. Esa dimensión natural cohabita con la precariedad económica de la familia que la película retrata. Si bien algunos personajes parecen más integrados que otros a los ritos e instrumentos de la modernidad, todos comparten ese mundo-dela-vida $a^{9}$ campesino y natural, un lugar que los sitúa en los márgenes de lo que se entiendo por desarrollo, donde las infraestructuras de transporte no llegan todavía y el caballo sigue siendo medio de desplazamiento. El sentimiento de pertenencia de los cuatro personajes de la familia pasa, en buena medida, por ese pedazo de tierra 'natural' que deben intervenir y domesticar diariamente para sobrevivir.

Esa proximidad a la naturaleza -y en oposición a la vida de las grandes urbes- pone en escena resabios de un Chile 'tradicional', que todavía reposa sobre la ejecución de labores artesanales que la vida moderna va sustituyendo por procesos estandarizados y artificiales de producción. El entorno campestre aparece imbricado a los denominados estilos de vida tradicionales.

En una secuencia, por ejemplo, la cámara nos muestra con minuciosidad las operaciones de la abuela preparando el queso fresco que luego tratará de vender a los automovilistas que cruzan la carretera (figura №3). La imagen pone en escena el tratamiento delicado que establece la mujer con sus materiales, el gesto de sus manos manipulando las telas y remojando la leche. El encuadre se concentra en esta extraña e 
íntima experimentación donde mano, cabeza y materialidad se entremezclan para producir algo nuevo.

Figura 4: La abuela vendiendo queso fresco en la carretera

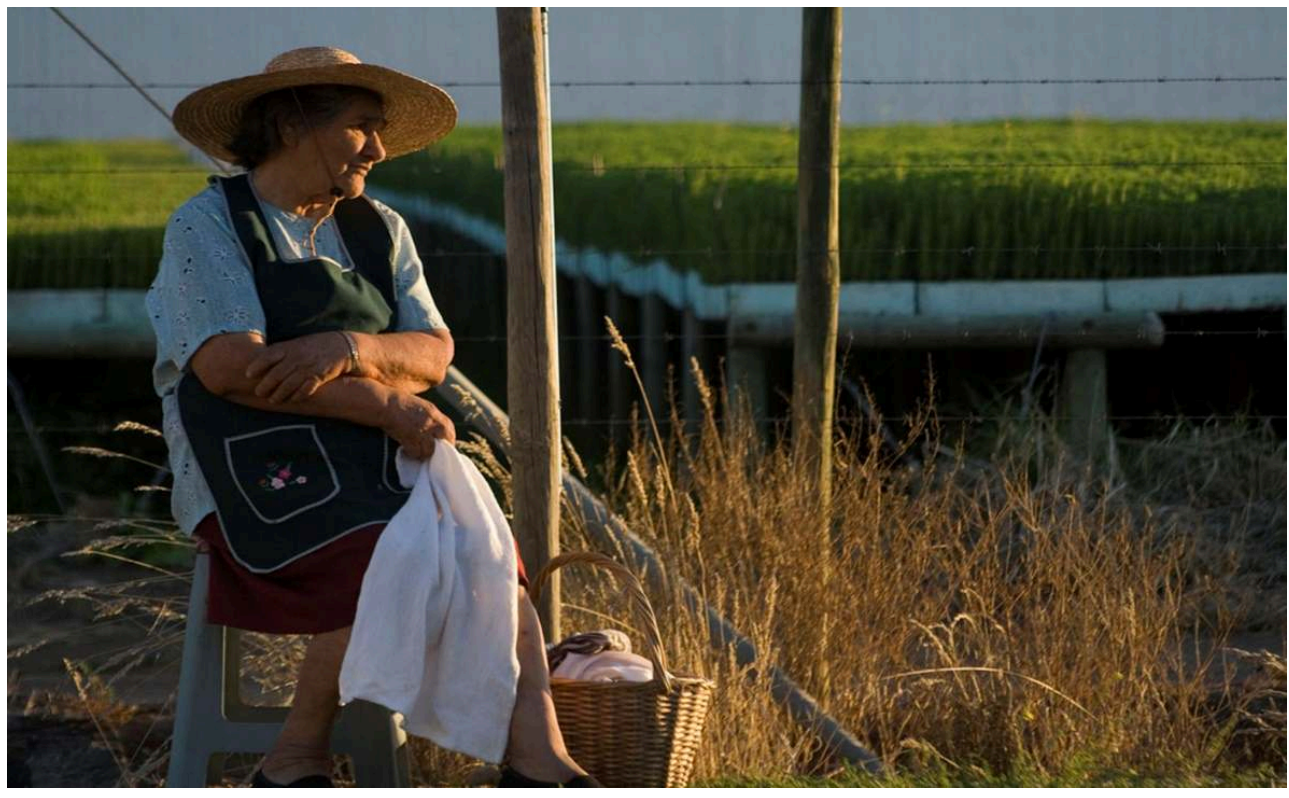

En este mismo registro, en otra escena seguimos detalladamente los pasos del abuelo cortando un tronco. En un paisaje deshabitado de fondo, sin música instrumental y solo sonido ambiente, la cámara acompaña al abuelo en la totalidad de su faena, desde el momento en que extrae la materia prima hasta cuando entierra el palo para levantar algo que desconocemos, posiblemente una cerca. Observamos su cuerpo moverse y la gota de transpiración en la frente, la sed en la boca y las destrezas técnicas de su mano maniobrando el hacha. A través de esta sucesión de planos, Fernández Almendras nos muestra al hombre de campo chileno, taciturno y cansado, que al rato buscará un lugar sombreado para dormir una siesta. 
Figura 5: El abuelo en el campo

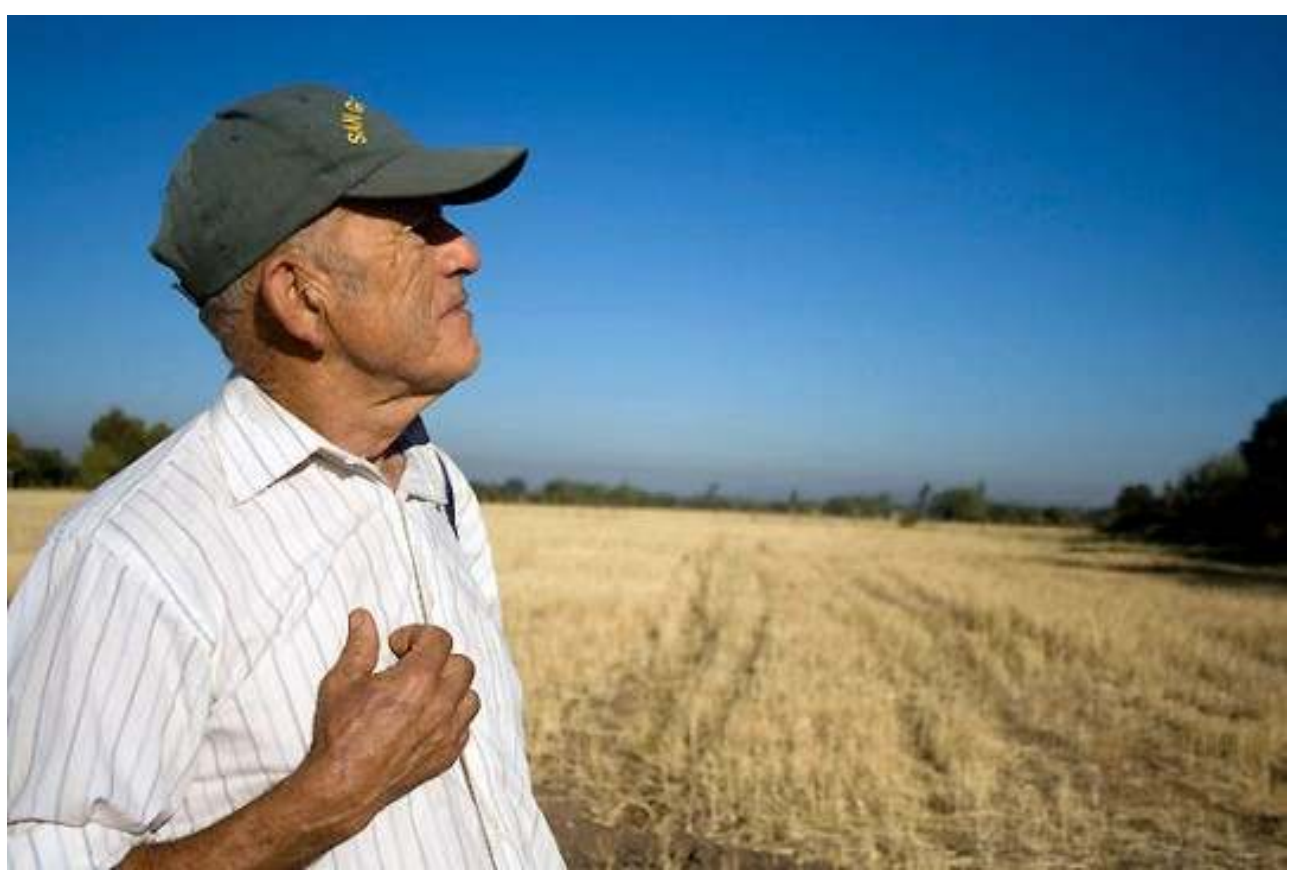

Estas dos secuencias -en las que proliferan los tiempos muertos y la utilización del cuerpo como herramienta de trabajo- tienen el mérito de generar una distancia crítica con el Chile de postal ${ }^{10}$. Al mismo tiempo, son secuencias que permiten situar, material y operacionalmente, ese imaginario del Chile campesino. De cierta forma la estrategia narrativa del director territorializa esa retórica cultural en torno a la vida tradicional en Chile, asociado a una serie de valores, principios y costumbres. La denominada 'identidad nacional' no es ritualizada ni fetichizada, ni transformada en una entelequia.

En el ámbito de la escritura, la artificialidad versus la autenticidad también es motivo de controversia. La poesía de Parra, por ejemplo, se alzó desde la publicación de Poemas $y$ antipoemas (1954) en contra el lenguaje poético del modernismo latinoamericano -del cual Neruda parecía ser el último gran exponente-, criticado por "afectado", "pomposo" y "artificial", promoviendo un retorno a la vitalidad del habla coloquial. ¿Cómo no va a ser más natural - espontáneo, auténtico - el "discurso huaso", chillanejo y acampado, de Parra, comparado a la pomposa grandilocuencia de Neruda ? El habla coloquial se precia de tener "los pies bien puestos en la tierra". Le llama al pan pan y al vino vino.

Incluso Zurita, heredero de la antipoesía en muchos aspectos, y que alterna entre lo coloquial y el desgarro de la sintaxis y las correspondencias de género y número ("mis amigos creen / que estoy muy mala / porque quemé mi mejilla"11), ejerce esta violencia en el lenguaje del poema no como una artificialidad provocadora y superficial, sino que como un reflejo de una concepción descentrada del sujeto, cercano a la locura, y que configura en Purgatorio, al decir de Waldo Rojas, una verdadera "esquizopóiesis"12, aunque también ha sido interpretada como reflejo de las múltiples formas de violencia ejercida por la dictadura. Se trata, entonces, de un lenguaje que, si bien puede chocar por su diferencia, sería acorde al descentramiento del sujeto y del contexto dictatorial en el que se sitúa. 


\section{Amenazas modernas}

19 En los "Ecopoemas", la naturaleza es amenazada por la modernidad, sea cual sea el sistema económico-político vigente. Ya en "Los Vicios del Mundo Moderno", Parra señalaba que lo propio de lo moderno son las "flores artificiales"13. Y a la oposición entre lo natural y lo artificial, superponía la oposición entre naturaleza-modernidad. La "atmósfera envenenada" de nuestro tiempo la sufren incluso los "industriales modernos". El mundo moderno es "una gran cloaca". Es desde esta interpretación de la historia -a pesar de que en el "Soliloquio del Invidividuo", en el mismo Poemas y antipoemas, se señala que "la historia no tiene sentido"14"- que Parra concibe los "ecopoemas"15.

En el caso de Zurita la naturaleza no aparece como amenazada por la modernidad. Sin embargo, para referirse a la escritura en el desierto, en una entrevista con Juan Andrés Piña, este se refiere a ella comparándola con los geoglifos de la cultura precolombina $\mathrm{Nazca}^{16}$. Resurge, desde el exterior de la escritura misma (la frase "ni pena ni miedo" nada parece decir sobre la naturaleza), la idea de la poesía como una práctica que, más que volcada hacia la modernidad, efectúa un retorno a una práctica pre-moderna.

Por otra parte, los soportes naturales escogidos por Zurita, el cielo de Nueva York en un caso, el desierto de Atacama en el otro, se caracterizan por ser "puramente" naturales. Son las hojas en blanco en que el lenguaje humano puede proyectarse. En las fotografías de la escritura en el cielo no se ven los rascacielos de NY, símbolos de la modernidad capitalista y uno de los más poblados del planeta. El trozo de desierto escogido del desierto, mientras tanto, ubicado al sur de Antofagasta, es un pedazo inmaculado de desierto.

De esta forma, se refuerza la idea de una naturaleza pura, no-humana, y que, de cierta forma, es intervenida en su pureza por el hombre. No hay, en todo caso, nostalgia de esa pureza una vez que la escritura pareciera transgredirla. La transgresión, en cambio, realza las dimensiones y temporalidades de lo natural, distintas -si no opuestas- a la humana.

23 En el caso de Huacho, y como se mostró precedentemente, los elementos pertenecientes a un mundo tradicional son, desde cierto punto de vista, fáciles de clasificar y encasillar. Su capacidad de designar lugares, paisajes y actividades de un chile de campo, posibilita rápidamente la producción de interpretaciones binarias y purificadas. En efecto, la gran mayoría de los comentarios y críticas sobre la película de Fernández Almendras tienden a coincidir -como una suerte de consenso tácito- sobre este punto: el film retrata la tensión entre campo y ciudad, tradición y modernidad, subdesarrollo y desarrollo ${ }^{17}$.

Bajo esta mirada, la película estaría orquestada para denunciar las paradojas de la modernización: un Chile invisible y olvidado, pobre y campesino, que resiste silencioso en la precariedad, ante la promesa de una vida moderna. Mientras que "allá afuera", en la ciudad, se configura un mundo de consumo, de celulares y arribismo. Un lugar donde la tierra y la naturaleza pierden significado en sí para pasar a ser consideradas como un medio para ejecutar fines humanos.

Desde esta lectura, la tensión de la película es bastante clara, con dos esferas nítidamente separadas que el espectador no tiene más que descubrir: un mundo en 
agonía, que hace referencia a lo natural, artesanal y campesino; y por otro lado, un mundo en proceso de expansión que alude a lo artificial, contaminado y estandarizado.

Esta tensión, bastante comentada por los críticos ${ }^{18}$, aparecería objetivada en los propios personajes: si los dos abuelos representan ese mundo pre-moderno apegado a la naturaleza; en contraste, la madre y el hijo representan el ascenso social y, sobre todo, el "padecimiento"19 de un sistema de valores capitalista. Por ejemplo, el niño, que rechaza las anécdotas del pasado de su abuelo en la mesa, al mismo tiempo hace lo posible con tal de usar el sofisticado gameboy que su compañero de curso no le presta, delatándolo al profesor. Por su parte, la madre -víctima de la sociedad de consumo, y frente al rechazo de su empleadora de un pequeño adelanto- debe devolver su vestido recién comprado en una multitienda.

No hay ninguna duda de que la historia de Huacho puede ser leída desde esta óptica del "padecimiento". La película es la ilustración del desmembramiento progresivo de un mundo tradicional (asociado a una naturaleza originaria y a prácticas artesanales) frente al despliegue de la lógica del mercado fundada en individuos egoístas. Desde esta perspectiva, la película pondría en escena el proyecto moderno y sus impactos perversos en la vida tradicional.

Con todo, y más allá de sus tratamientos diversos, es claro que estas tres obras abordan elementos que podemos ubicar dentro de las categorías de lo que se entiende normalmente por "tradicional", "natural", "moderno", etc. Hasta aquí, y como se ha podido notar, hemos buscado reproducir lo que nosotros denominamos como interpretación dualista de estas obras.

\section{El desborde de las transparencias}

29 A partir de las entidades purificadas que describimos en la sección precedente, las posibilidades de interpretación y experimentación se reducen. Las evidencias ya están puestas sobre la mesa, catalogadas y rotuladas, y las obras no harían otra cosa que representar un mundo preexistente.

En la primera parte entonces, hemos reconstituido un discurso sobre la naturaleza que reposa, en buena medida, sobre la oposición entre naturaleza y cultura por una parte, entre un afuera y un adentro, por otra ${ }^{20}$. Sin embargo, para que la naturaleza emerja es inevitable pasar por dispositivos y mediaciones. Dicho de otra manera, ella no existe al margen de ciertas relaciones, organizaciones y disposiciones socio-materiales. $Y$ el cine, la poesía o la fotografía, a nuestro parecer, no hacen más que subrayarlo.

\section{Mediaciones}

Nosotros mismos, para abordar este tema, no estamos afuera de estas mediaciones ${ }^{21}$. No tenemos acceso transparente a la naturaleza desde el cual proceder metodológicamente. Así, parte de este trabajo se realizó en la sala de lectura para investigación de la Biblioteca Nacional de Francia (BNF) ${ }^{22}$. La 'naturaleza' que buscamos para escribir este texto, sólo nos resulta accesible a través de una institución. Y, de manera más imperceptible aún, gracias a un estatuto que nos autoriza el ingreso a ella. Por otra parte, para llegar a esos libros, también es necesario, hasta cierto punto, el uso de una lengua distinta a la que estamos acostumbrados a utilizar, ya sea para rellenar 
los formularios en francés, retirar los libros con el bibliotecario, reservar los libros en el sitio web de la institución, etc.

Lo mismo puede ser dicho sobre nuestras estrategias para acceder a la película. Un conocido nos habló de ella. Pero el trabajo de Fernández Almendras ya había salido de cartelera. Y verla -intentar verla, en realidad- se convirtió en una tarea engorrosa. De hecho, pasamos horas frente al computador tratando de encontrar cómo hacerlo. Nuestras reflexiones sobre naturaleza y arte en Chile se transformaron súbitamente en discusiones sobre cómo bajar la película. Luego de varias piruetas, pudimos descargarla en una carpeta de dropbox y, a través de dos clics, en una pantalla de 15 pulgadas y con subtítulos en inglés totalmente innecesarios, finalmente accedimos a la 'naturaleza' de Huacho.

Las mediaciones que nos permitieron ver la película y acceder a los libros no deben entenderse como simples herramientas de reproducción de una realidad que le preexistía, sino como técnicas que efectuaron definiciones del mundo, formulando modos de existencia ${ }^{23}$ a los elementos que deseábamos indagar. Debimos, para decirlo concretamente, pasar por una serie de instrumentos, artefactos e instituciones antes de sentarnos a escribir sobre la relación naturaleza/cultura que propone el dossier.

\section{Dispositivos: el caso de la escritura}

Una característica evidente de la escritura de Zurita y Parra es la de remitir a una lengua específica -el castellano. El castellano escrito es un código enseñado y cuya reglamentación depende de distintas instituciones (Ministerios, escuelas, universidades, RAE, etc.). En ese sentido, la naturaleza emerge como tal al interior de esas convenciones de escritura enseñadas. Por otra parte, la escritura del castellano no está desconectada de la práctica hablada (no así las llamadas lenguas muertas) y de sus juegos de connotación. Esto abre la escritura y su sistema de convenciones a una serie de relaciones posibles con el habla.

Las alteraciones de la convención escrita en los "Ecopoemas", por ejemplo, pasan por un mayor acercamiento de la escritura a formas habladas. Parra inventa recursos tipográficos que sugieren la frescura de ciertas formas de hablar. El uso de las mayúsculas, por ejemplo, sirve para enfatizar cierto tipo de pronunciación con respecto a palabras en minúscula. Los poemas que utilizan solo minúsculas muestran cierto desapego a la convención que es indisociable de la crítica a las estructuras sociopolíticas responsables del paso del "MUNDO actual" al "inMUNDO actual" 24 .

En la escritura del desierto, en tanto, lo que parece estar en juego es una grafía de aprendizaje. Los trazos circulares de la frase "ni pena ni miedo" sugieren una escritura infantil, una escritura que está recién siendo aprendida. Sin embargo, en la fotografía no aparece el contexto de ese aprendizaje. Si trasladamos la frase al contexto de aprendizaje por excelencia -la escuela- la tarea caligráfica del niño podría haber sido corregida por dos motivos: la frase no comienza con mayúscula y falta el punto final. Sin embargo, en la fotografía, no hay ningún elemento que sugiera una corrección o, incluso, un castigo, sugiriendo un aprendizaje libre de correcciones e imposiciones normativas.

37 En la medida en que el dispositivo de la escritura es utilizado también para configurar lo social y lo individual, definiendo espacios abiertos y privados (el "yo", el "nosotros", 
el "ellos", etc.), cada acto público de escritura o habla irrumpe en la configuración de lo individual, lo colectivo, lo humano.

De esta forma, cuando Parra tilda, en "Los siete chanchitos. Himno oficial del movimiento ecológico", de "CHANCHO CON CHALECO" 25 a quienes no cuidan la realidad ecológica, no basta con concluir que Parra, en el contexto de los años ' 80 , delimita una frontera entre los ecologistas (entre los cuales él, autor del himno, se incluye) y los otros, sino que también podemos preguntarnos de qué manera esa frontera es o no es retomada, en el contexto de hoy, por nosotros. Cuando la naturaleza emerge en el dispositivo lo hace en una instancia en la cual nosotros mismos no podemos desligarnos de participar en la actividad de configuración.

La naturaleza, en todo caso, emerge irreductiblemente asociada a esa frontera. Por otra parte, la elección de un chilenismo para designar a quienes son los enemigos del medio ambiente, al mismo tiempo que sitúa a los ecologistas en el bando de quienes utilizan el habla coloquial, parece acotar la extensión del movimiento al contexto chileno.

Figura 6: "Escrito en el desierto"

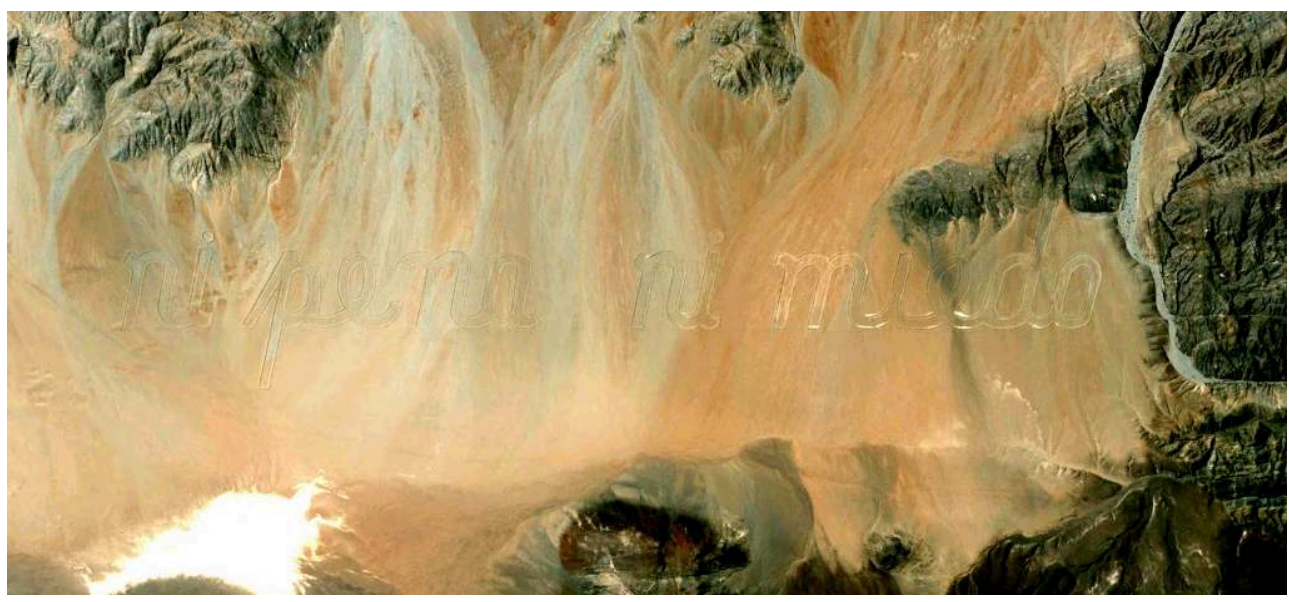

La Vida Nueva, p. 520-521 fotográfico construye una mirada panorámica, casi satelital, que implica un dominio del territorio que sobrepasa a la experiencia común y se apoya en la tecnología como extensión de las posibilidades del cuerpo humano. La tecnología aeronáutica, junto con la fotografía, construyen esta mirada desde el cielo que, en cierto modo, es la mirada del narrador omnisciente, que todo lo sabe y todo lo ve. Es esa mirada, que se asemeja al poder anónimo de la modernidad, el que borra las pertenencias del discurso, generalizándola ${ }^{27}$. 
43 Es interesante en Zurita que la mirada desde las alturas, por implicar un ojo omnisciente, controlador y panóptico, hace emerger la naturaleza también como un plano de coordenadas en que surgen elementos observables. Esta abstracción de la naturaleza puede reforzar la ilusión de que se trata realmente de la naturaleza que está "allá afuera". Sin embargo, la naturaleza es indisociable de su condición de soporte de escritura. El desierto es a la vez naturaleza y lugar de escritura. Se trata de un lugar híbrido en que la yuxtaposición es una intervención en sír ${ }^{28}$.

El carácter abstracto en la fotografía del desierto en Zurita contrasta, sin embargo, con una saturación de significados asociados a él. Como dice Zurita en entrevista con Piña, el desierto es:

la imagen más profunda y exacta de lo que es el alma contemporánea: su aparente nada, pero para la cual basta un cambio de luz al ponerse el sol, para que se transforme absolutamente en otra cosa. Aridez total, y al mismo tiempo una cierta grandeza que sobrecoge 臨...垉. El desierto siempre ha sido algo muy fuerte para mí: está cargado de símbolos y metáforas ${ }^{29}$.

El desierto es un espacio híbrido, situado en el cruce entre las inducciones del dispositivo de mediación y las proyecciones del observador, y que emerge de este encuentro en medio de afectos, emociones e ideas.

La escritura, por otro lado, emerge en una fotografía tipo satelital de reconocimiento topográfico. La planicie de la escritura se confunde con los relieves de la geografía. No solo pueden observarse los cauces secos de las quebradas. La verticalidad de esas líneas contrasta con la horizontalidad de la lectura. En los márgenes de la fotografía, se notan los relieves de las montañas, que se distinguen de la planicie en la que se excavaron las letras.

47 Por otra parte, la solidaridad entre lo moderno y la naturaleza es evidente. Es gracias a los dispositivos de mediación y sus modos de difusión que surge la naturaleza como un objeto ante el público, y es la tecnología aeronáutica la que hace posible que surja una visión omnisciente de la naturaleza, una visión sin secretos para la mirada humana, a diferencia de la mirada en terreno que no sería capaz de percibir la escritura si estuviera en el lugar.

\section{Acerca del naturalismo de Huacho}

48 Tanto las imágenes del cine como la escritura literaria escenifican mundos. Pero sería un error oponer realidades ficcionales a realidades objetivas. Como ya ha sido subrayado, no es posible hablar de una realidad "allá afuera" sin pasar por alguna mediación que la haga posible, provocándola y configurándola. En el caso de Huacho, hay una estrategia narrativa clara a la hora de mostrarnos lo natural, lo tradicional y lo moderno. Una opción que obliga a percibir ciertas cosas y no otras.

49 La película está compuesta por segmentos distintivos y cada uno pone en escena las actividades cotidianas de los cuatro personajes principales. Al estilo de los realizadores belgas Jean-Pierre y Luc Dardenne, el relato muestra hechos y acciones; jamás explicaciones ni justificaciones. Esta actividad de descripción densa ${ }^{30}$-para utilizar el concepto del antropólogo Clifford Geertz (1973)- es llevada a su máxima expresión a través de una cámara que acompaña a sus personajes en sus recovecos más discretos y silenciosos. No parece presuponer a priori sociológico ni psicológico, solo manifestaciones, gestos, actos, usos, prácticas, que vemos sucederse sin música y casi 
sin palabras. Se trata de una opción por componer un mundo depurado de accesorios, donde la cámara de Inti Briones, director de fotografía, puede pasar largos segundos mostrando a la madre y el hijo sentado en un mismo asiento del bus que los lleva de vuelta a la parcela.

Huacho procede aplanando y describiendo el mundo donde habitan los personajes. Es un movimiento hacia lo concreto, donde la necesidad de poner las cosas en sus "contextos" es reemplazada por el registro de los singular y particular. La cámara suspende toda forma de sentimentalismo para concentrarse -a través de encuadres cerrados y de una economía narrativa extremadamente calculada- en el registro pragmático de las múltiples entidades y ritos que configuran el universo familiar: los pastizales y la oración matutina, el abuelo lavándose en el baño y la abuela dándole de comer al perro y las gallinas, el hijo que se devuelve a apagar la luz para seguir durmiendo y el colegio de Chillán, el desayuno en la mesa y el viaje hacia el trabajo, el sol quemando en la carretera y la conversación con los colegas, etc.

El melodrama es sustituido por el encadenamiento de prácticas que lucen normales y simples, radicalmente pedestres. La idea del Chile auténtico o profundo, es subvertida por la idea de un Chile que resiste el día a día las paradojas de un país en construcción.

Pero el naturalismo de Huacho está lejos de pretender revelar una identidad 'nacional'. En primer lugar, porque su postura descriptiva no reposa en la ilusión de la trasparencia. Aquella que pretende una reproducción del mundo tal-cual-es, como algo que preexiste a los medios imbricados en la acción de mostrar. Por el contrario, las estrategias técnicas del director descritas anteriormente son demasiado explícitas como para caer en esta ilusión. Es un cine que nos muestra sus gestos, sus cortes, sus fundidos a negros, su prosa materialista, su re-presentación sucesiva, en fin, su política de lo visible e invisible, como diría Jacques Rancière ${ }^{31}$. La tentación de un registro aséptico, transparente y naturalista, es subvertido por ese trabajo político de 'hacer visible' el mundo.

En este sentido, Huacho se ubica en las antípodas del ideario costumbrista latinoamericano o de un Chile de postal. No hay pretensión de dar cuenta de una especie de pathos nacional, ya que eso supondría un macro-relato que escapa a las pretensiones narrativas de la película. El cine de Fernández Almendras se rehúsa a la especulación y al metalenguaje identitario, para ofrecer conocimiento situados, corporizados. Es un cine amablemente materialista. 
Figura 7: el abuelo camino a la faena

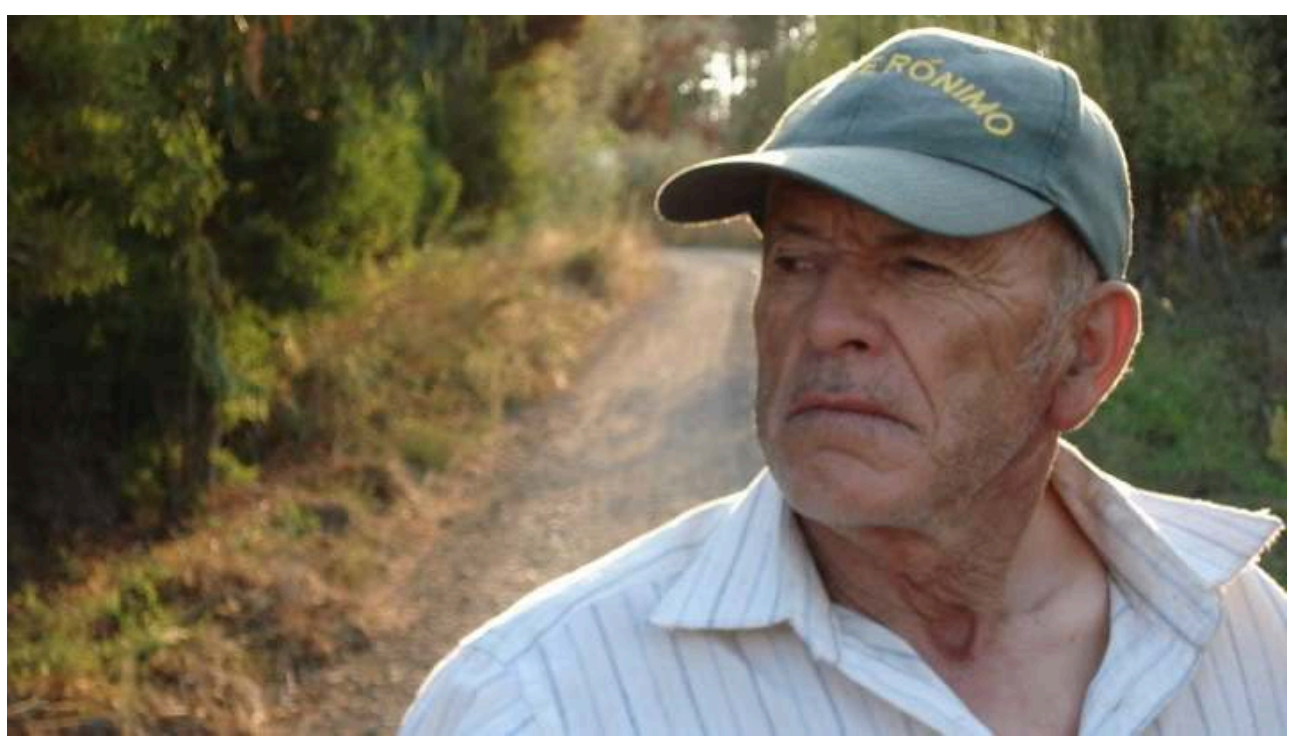

Por último, no es casualidad que Fernández Almendras haya escogido un reparto de actores no profesional. Hay un rechazo a los gestos y cuerpos estilizados del cine comercial para hablar del campo ${ }^{32}$. La cámara del director no para de recordarnos que lo que estamos presenciando no es un feel good movie ni una teleserie. La historia de los personajes va a seguir escribiéndose, con o sin cámaras al frente. El uso de actores noexpertos es además una forma de reintroducir la tensión artificial/natural en los mismos materiales cinematográficos que hacen la película y constitutivo, a su vez, en la discusión sobre la ontología del cine ${ }^{33}$.

\section{Naturaleza, pertenencia y discurso}

En el caso de Parra, la naturaleza no emerge en medio de una saturación, en el sentido de una sobrecarga simbólica o metafórica. En cambio, emerge asociada a discursos sociales (del comunismo, al capitalismo, el ecologismo), desde un punto de vista irónico y escéptico. Los "ecopoemas" pueden ser leídos como lugares en que un sujeto irónico y escéptico manipula discursos sociales en vistas de poner sobre la mesa pública la necesidad del ecologismo, bajo la hipótesis de que los discursos son correlatos de acciones que producen efectos en la naturaleza.

Bajo esta hipótesis implícita en los "ecopoemas", la escritura adopta una ética correctiva. Los discursos juzgados nocivos al equilibrio ecológico son distorsionados y transformados en dirección de esta nueva preocupación:

dice: proletarios del mundo uníos

debe decir

peatones del mundo uníos ${ }^{34}$

57 Se conmina a pasar del lema "proletarios del mundo uníos" a "peatones del mundo uníos" - creando la necesidad de una redefinición de las prioridades colectivas. Lo ético surge como un "debe decir", lo que decimos y hacemos no se corresponde con el deber de actuar en protección de la naturaleza.

En otro de los "ecopoemas", Parra retoma en verso parte de la respuesta que el jefe indígena Seattle le envía en 1856 al gobernador de Washington Isaac Stevens, 
aceptando su propuesta de compra de tierra aunque manifestando su incomprensión por el principio mismo del acto:

El error consistió

en creer que la tierra era nuestra

cuando la verdad de las cosas

es que nosotros somos de la tierra ${ }^{35}$

El jefe Seattle critica al hombre blanco por creer que es dueño de la tierra cuando la verdad es justo lo contrario. Esta redefinición de la pertenencia es clave para entender las manipulaciones discursivas en los "ecopoemas". De hecho, ya no importaría ser de tal partido o tal otro, o ser dueño de, sino comprender la pertenencia de la especie humana a la Tierra-naturaleza. El hecho de borrar la cita, y de incorporarla en los "ecopoemas" asumiendo retrospectivamente la lógica del jefe Seattle ("el error consistió") para asentar una verdad firme ("nosotros somos de la tierra") muestra también la manera en que Parra desplaza discursos con el fin de incorporarlos en su propio proyecto, redefiniendo el sentido del "nosotros".

Es desde esa necesidad que surge la posibilidad de distanciarse de la visión edénica de la naturaleza presente en el himno de Chile:

Puro Chile es tu cielo azulado

chiste ecológico

puras brisas te cruzan también

¿vai a seguir? ${ }^{36}$

61 Es el quiebre de ese sentido de pertenencia el que generaría la crisis ambiental que, dicho sea de paso, se caracteriza por la violación flagrante del código natural tradicional: al aire puro se opone al smog, las especies animales se ven amenazadas (cisnes), etc. La naturaleza pierde su calidad de locus amoenus y pasa a estar ella misma en riesgo de extinción debido, entre varios factores, al peligro nuclear. Lo cierto es que la naturaleza emerge como objeto de debate en discursos más o menos reificados y que, según los "ecopoemas", producirían efectos de realidad determinados. La asociación entre discurso y efecto de realidad implica que la naturaleza es, entre otras cosas, un lugar del discurso.

\section{Eventualidades inestables}

62 Hemos dicho que a pesar del registro 'documental' de Huacho, el trabajo del realizador no se reduce a una operación representacional. La cámara cumple una función activa y severa de intervención del mundo. Hay una reivindicación de la cámara como mediación, como experiencia. Tampoco busca hacer disponible un mundo ya formalizado. El suyo es un proyecto que hace emerger una incertidumbre respecto a las articulaciones que hacen comunidad, o si se prefiere, muestra formas de encuentro no totalmente cristalizadas. La cámara abre posibilidades y espacios de experimentación, en el sentido de que ensambla elementos que escapan a los dualismos.

Las dos escenas señaladas previamente -donde seguimos las labores de la abuela con el queso fresco y el abuelo cortando un tronco- son una buena ilustración de esta indeterminación. Las secuencias están construidas de manera tal que no sabemos si efectivamente hay un ser humano 'cultural' (la figura del campesino luchando contra su entorno) que manipula una naturaleza muerta; o si el sol, las telas, la leche, los animales y los pastizales, igualmente actúan sobre esos personajes. 
Figura 8: El abuelo durmiendo siesta

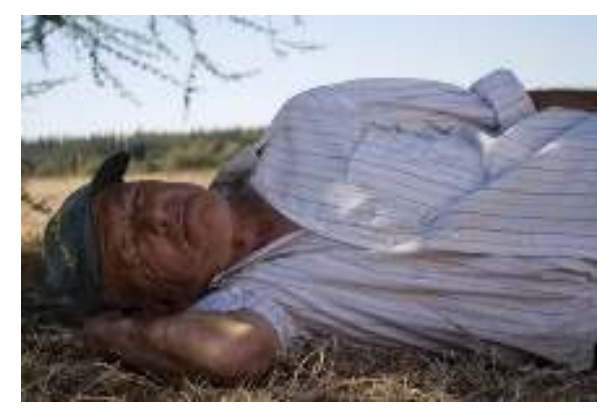

La cámara filma la acción de producción de queso fresco y de un pedazo de madera. Vemos ambas materias entrelazarse con los cuerpos de los personajes. Pero sería injusto afirmar a ciencia cierta, que se trata de una acción enteramente controlada y dirigida por los 'personajes sociales' (la abuela y abuelo), ya que las secuencias muestran también cómo el calor hace transpirar y dormir una siesta al abuelo; y por otro lado cómo la sequía hace aumentar el valor de la leche, obligando a la abuela a vender más caros sus quesos al borde de la carretera. compañía de la televisión. “¡Y otra vez!" pronuncia la madre. Manuel - enojado primero porque su abuelo le saca cucharadas escondidas de su Cola-Cao - sale corriendo a verificar si un problema en los tapones eléctricos de la casa había provocado el corte. La madre se da cuenta de que no ha pagado la cuenta de la electricidad. El problema no es técnico, sino económico. Minutos más tarde - en la sección dedicada a la madre - la veremos disfrutando por última vez un vestido que tendrá que devolver en el mall de Chillán para poder pagar la cuenta de luz.

Las categorías puras esconden siempre peligros de desborde. Es lo que se ha tratado de mostrar hasta aquí: desbordes porque no sabemos si la naturaleza está dada u oculta, si es algo externo o interno a la cultura, ni quién interviene primero, si la naturaleza o los seres humanos. La pureza de la naturaleza es siempre el resultado de una 
invisibilización de ciertas demarcaciones y operaciones que revelan la dificultad de trazar una frontera estable entre lo natural y lo no-natural.

Como veremos a continuación, estas operaciones son políticas y controversiales, pues despliegan definiciones ontológicas en pugna que determinan la manera de hacer visible, jerarquizar o imponer un determinado modo de ordenar y distribuir el mundo.

\section{Políticas de la naturaleza}

\section{Configuración 1: la disponibilidad vulnerable}

70 Como hemos visto a través de los últimos ejemplos, la naturaleza emerge en lugares híbridos, indisociable de los dispositivos de mediación, y de la carga y saturación simbólica, metafórica, afectiva que surgen del encuentro entre el observador y el dispositivo. Esto significa pasar del paradigma representativo del arte a un paradigma configurador de realidad. La naturaleza, por lo tanto, ya que no es un afuera autónomo, se constituye también a través de actos de configuración. En esta sección, intentaremos mostrar qué naturaleza se configura en cada trazo, prestando particular atención a la dimensión política de esta configuración.

71 La naturaleza que emerge de los "ecopoemas" es una naturaleza amenazada por los efectos que la modernidad produce sobre ella ${ }^{38}$. Parra subraya la relación entre tipo de discurso y tipo de naturaleza o efecto de naturaleza, propugnando un cambio ético a nivel de discurso que pasa por una ecología, entendida esta como un discurso basado en el deber de recordar la pertenencia del hombre a la naturaleza. Por eso, los procedimientos que utiliza Parra cortocircuitan constantemente los eslóganes políticos de la época -los ' 80 en plena dictadura- para aplicarles, mediante la ironía, el sarcasmo o el desplazamiento, una corrección en dirección de la ecología.

Los discursos sociales son intervenidos por un sujeto -Parra- para restablecer un nuevo $\mathrm{u}$ olvidado deber. Sin embargo, incluso este deber es puesto en ridículo en ocasiones como cuando Parra dice que ya sabemos "QUEL MUNDO SE ACABÓ" 39 o cuando se declara un "catastrofista moderado" ${ }^{40} .$. En cierta manera, Parra promueve un retorno a algo que los "vicios del mundo moderno" habrían vuelto intolerable. El cambio promovido por Parra implica la creación de una nueva colectividad que no pasa por las definiciones nacionales, sino que las sobrepasa.

Zurita, en cambio, con su apuesta por la monumentalidad, propone una naturaleza doble. Por una parte, la naturaleza es un espejo en que el hombre puede aprender a descifrarse. Por otra, es un lugar a su disposición, que puede ser intervenido, utilizado, sometido a la voluntad humana. En la medida en que se monumentaliza la escritura, también se rinde un tributo a la grandeza del paisaje en línea con cierta idea de Chile como país de paisajes. La concepción de Zurita en la escritura del desierto limita con la estética de la postal, constituyendo la escritura como monumento inscrito en la naturaleza.

74 En el caso de Zurita la naturaleza no se encuentra en riesgo, como en el caso de Parra. Al contrario, ella emerge como disponible para el hombre y, además, como disponible “al menos por 800 años" ${ }^{4}$. Esta visión utilitaria de la naturaleza continúa, en cierta medida, el lema de Vicente Huidobro, que proclama en su manifiesto "Non serviam" la autonomía del arte frente a la naturaleza: "No he de ser tu esclavo, madre Natura; seré 
tu $\mathrm{amo}^{42}$." Esta disponibilidad es doble: como espejo y como soporte. En este sentido, la naturaleza, tal como emerge en la escritura en el desierto, no se aparta mucho de la visión tradicional de la naturaleza, la diferencia se sitúa en la función que se le asigna a la poesía frente a esa naturaleza.

En ambos casos, la naturaleza que se configura en las obras es pasiva. En el caso de Parra, la naturaleza es víctima. Nuestros discursos se traducen en actos que la deterioran $\mathrm{y}$, por lo mismo, reducen nuestra calidad de vida al deteriorar nuestro entorno. En el caso de Zurita, la naturaleza es soporte. Como tal, se presupone una cierta estabilidad que la fotografía captura en un instante determinado y la encuadra. Si bien Zurita no busca proteger a la naturaleza, podemos suponer que, en la medida en que esta simboliza al ser humano en su integridad, cualquier intervención sobre ella es también una intervención en la imagen del hombre.

\section{Configuración 2: zonas en elaboración}

76 Lejos de lo que se suele denominar como cine militante o panfletario, las operaciones efectuadas por Huacho pueden considerarse como un proyecto esencialmente político. Pero no en el sentido moralista del término, como si hubiera una suerte de imparcialidad trascendente desde la cual fuera posible denunciar o desmitificar el mundo. Es político por la investigación que propone, por los medios utilizados para describir las relaciones morales que se establecen de manera situada y que surgen siempre desde la exploración corporal de sus personajes.

77 A primera vista Huacho muestra la batalla de una familia por su bienestar material, y las piruetas que deben soportar sus personajes para lidiar con la precariedad económica y su integración a una lógica mercantil. Sin embargo, desde una lectura menos condescendiente $-y$ por ende, menos sociológica- estas secuencias no muestran dos esferas del mundo en confrontación (modernidad v/s tradición) sino más bien zonas en construcción. La retórica de la modernidad lineal, con todas sus promesas, representadas en las escenas de la televisión encendida, el mall, el video juego, la electricidad, etc., no se imponen inmunes y lisas sobre un paisaje antiguo, retrógrado, tradicional. Por el contrario, Huacho nos señala personajes contradictorios, prácticas que subvierten esta linealidad. El gesto de usar una prenda sin cortarle la etiqueta para luego poder devolverla en el centro comercial, es una clara expresión de ello. Las 'tecnologías de la modernidad' no se instalan en la vida de esta familia, sino que deben co-habitar, redefinirse y ensamblarse con otras prácticas y actividades, haciendo emerger nuevas formas de encuentro y convivencia que no se reducen a la dicotomía promulgada entre moderno/tradicional.

Al final de la película, la luz se restablece (recordemos que la cita comienza con un corte de electricidad) y escuchamos la voz de un animador famoso de la televisión chilena acompañar el desayuno de la familia antes de comenzar sus rutinas.

\section{Otra política: el autor}

En el caso de Parra y Zurita, como hemos visto, la pasividad de la naturaleza es el resultado de operaciones y configuraciones múltiples. La pasividad de la naturaleza emerge "como si" la naturaleza fuera efectivamente así, pero es el resultado de una política de la naturaleza que guía la configuración de la escritura. Esta política de la 
naturaleza es indisociable, a su vez, de otras políticas que cruzan los "ecopoemas" y la escritura en el desierto de Zurita.

En ambos casos, por ejemplo, la política de la naturaleza pasiva remite a un sujetopoeta que articula esta pasividad y le da significado. En el caso de Parra, es la figura misma del antipoeta que resulta privilegiada con la intervención ecológica de los discursos sociales. Es él -como compositor del himno ecológico- el poeta que le da voz a un movimiento "adelantado"43, rearticulando la idea del poeta como portavoz político. La asociación de la figura del antipoeta a la lucha ecológica lo hace emerger como líder de un movimiento a su manera revolucionario ("hay que cambiarlo todo de raíz").

81 La naturaleza amenazada necesita de una rectificación que salvaguarde su verdadero sentido. Parra, durante un recital de poemas realizado en el Círculo de Bellas Artes de Santiago en 1987, se autocalificará de "alfabetizador ecológico", reforzando su imagen de predicador y docente, aun cuando en los Ecopoemas se distancia de su posición de salvador mediante la ironía y un pesimismo a toda prueba que por momentos le quita valor a su compromiso. En todo caso, la pertinencia de esos procedimientos en el contexto de la dictadura han sido objeto de crítica. Matías Ayala, por ejemplo, en su libro Un lugar incómodo (2010), pone en tela de juicio la pertinencia de la obra de Parra en el contexto de la dictadura:

Debido a que el espacio público está neutralizado, las frases contradictorias [...] se vuelven, entonces, pequeñas confusiones que Parra utiliza para mantener la apariencia de un trabajo discordante. [...] En el caso de la ecología de Parra, es imposible determinar cómo la resignifica, ya que la fragmentación de los "Cachureos" le excusa de encadenar un discurso crítico $^{44}$.

82 En otras palabras, la cuestión ecológica en Parra sería indisociable de una política de autor, en la que se trata de mantener el estatuto de "poeta nacional" caracterizado por su trabajo discordante ${ }^{45}$. La naturaleza también sería el motivo mediante el cual seguir alimentando la causa autorial parriana sin hacerse cargo de la neutralización del espacio público.

83 En el caso de Zurita, la naturaleza pasiva, en cambio, está inserta en estrategias de colectivización y personalización a la vez. Por una parte, según Germán Bravo, la frase "ni pena ni miedo", en el contexto de la transición a la democracia en el Chile de los años noventa:

...pretende dar cuenta de una experiencia histórica, no sólo de un quiebre político sino de un quiebre en las propias posibilidades de la comunicación y de la comunidad... e intenta sacar la lección de esa experiencia de quiebre de las capacidades comunicativas de la sociedad chilena para erigirse como una señal en el desierto que reindica las coordenadas de lo posible después del infierno ${ }^{46}$.

84 La impersonalidad de la frase traduciría el carácter colectivo -no personal- de la enunciación. Sería el pueblo chileno-oprimido por la dictadura- que escribe en su territorio su reinserción en la historia. Sin embargo, es interesante que nadie se haya detenido en el estatuto de territorio conquistado de ese soporte - durante la Guerra del Pacífico que opuso a Chile, Perú y Bolivia durante la segunda mitad del siglo XIX naturalizando y deshistorizando el territorio chileno. La apariencia infantil de la caligrafía vendría a significar este carácter de nuevo aprendizaje, esta apertura al futuro. Este voluntarismo histórico, que neutraliza la tensión entre pasado, presente y futuro, desplaza, según Nelly Richards, "el presente inquieto de las vanguardias" por el "presente aquietado (calmado, satisfecho) de la consagración institucional de la 'gran obra' ${ }^{\prime 7}$ ". 
85 En este sentido, es innegable que este carácter colectivo de la enunciación se ve enseguida "capturado" por la inclusión en un libro de y sólo de Zurita (la Vida Nueva). La asociación entre enunciación colectiva y autoría concentrada en Zurita, unida al gesto de clausura y apertura histórica, desemboca en la idea de "poeta de la transición". Este acercamiento a la "institucionalidad" pasa por contar con la asistencia del Ministerio de Obras Públicas (MOP) de Chile, un ministro de Estado y varios empresarios, para la realización de la escritura en el desierto ${ }^{48}$. Así, el observador de la fotografía, si bien ocupa desde una perspectiva omnisciente el lugar del control y del poder, se enfrenta a una escritura de aprendizaje que ya no hay que reprimir, sino que apreciar como un paisaje elaborado colectivamente y que contiene el futuro del país.

\section{Hacer y deshacer comunidades y naturalezas}

En Huacho, en cambio, la naturaleza parece co-existir en igualdad de derecho. En otra escena, seguimos a la abuela desplazarse por un camino de tierra empujando un carro de madera donde lleva un par de botellas vacías. Necesita comprar los litros de leche que le permitirán hacer los quesos frescos que venderá al borde de la carretera. Se detiene en un galpón en medio del campo, y mientras toma unos sorbos de agua, entabla una conversación sobre el 'mercado' de la leche en el sector. Nos sentimos espiando una conversación privada: un joven le informa a la señora que el precio de la leche subió a 250 pesos. Ella le pregunta si le puede dejar debiendo para la próxima vez pues no trajo tanto dinero, al tiempo que el vendedor le explica con culpa la situación: "si en todos lados subió el precio de la leche, si con esta sequía no crece ni pasto, jla vacas ni se alimentan ya!" La invocación a las causas naturales (la sequía) en el alza del precio de la leche aparece en la conversación de ambos personajes como algo que acontece, como una certeza que desborda las acciones puramente humanas. Incluso podríamos decir que el detalle del aumento del precio de la leche localiza una situación global vinculado a falta de lluvia en la zona. Pero al mismo tiempo, el recurso a la naturaleza no acontece como algo externo a sus vidas, sino como una naturaleza imbricada en la cotidianidad, localizada en pequeños encuentros y conversaciones.

En el encuadre siguiente, se muestra a ambos personajes arriba de una carreta, reconciliados después de la negociación. El joven conduce con una mano las riendas del caballo mientras con la otra habla por teléfono celular con su socio. Alcanzamos a entender que éste último le dice que deben encargar al pueblo más cd's del cantante Marco Antonio Solís, porque los clientes lo están comprando con ansias. La abuela, por de pronto, luce más bien indiferente a la conversación comercial, mucho más atenta a los movimientos del animal. Apenas corta la llamada, la señora recrimina al joven por la manera de conducir la carreta, y éste le responde, retomando con ambos brazos las riendas: “¡no se preocupe señora, si yo ya lo conozco ya!”. 


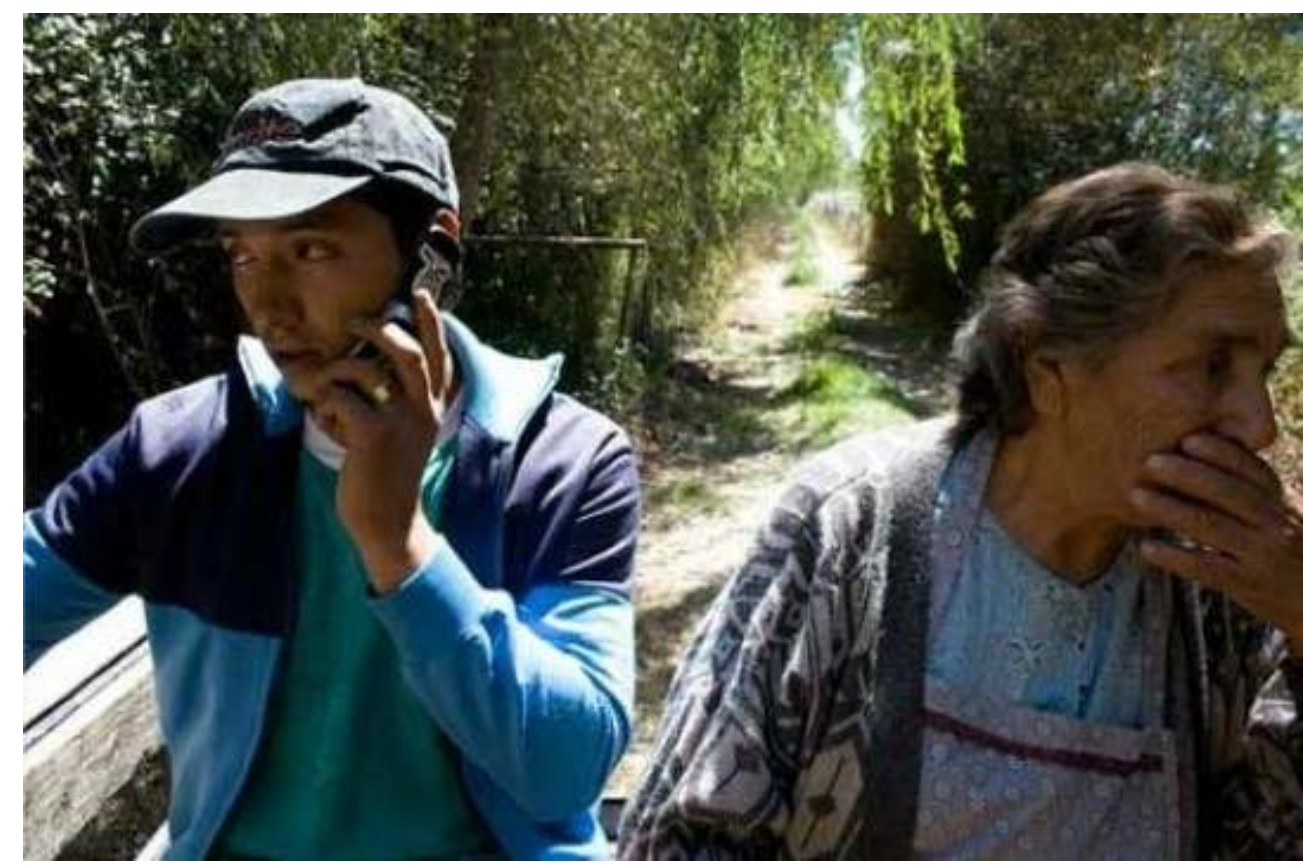

Esta secuencia que venimos de describir no dura más de un minuto y medio. No obstante, pone en escena una coexistencia de múltiples entidades: camino de tierra, carreta, humanos, el mercado de la leche en el campo, el caballo, botellas, emociones, teléfono celular, Marco Antonio Solís, yerbas, agua, sequía, etc. Desde una perspectiva dualista, es evidente que todos estos elementos son asumidos como pertenecientes a mundos separados (objetos de la naturaleza, de la cultura, de la modernidad...) donde sus funciones y roles están definidas de antemano. Se las somete al tratamiento de purificación, secuestrando todo lugar para lo inconmensurable, difuso, incierto.

La fuerza de este tipo de secuencias que propone Huacho reside en que resisten a la pretensión de la total disponibilidad y órdenes perfectamente solidificados. Son secuencias que dejan abierta las posibilidades de articulación. Las fronteras son difusas, por lo que determinar dónde empieza y termina la naturaleza y la cultura, lo moderno y lo tradicional, depende del observador, del lugar en el que esté situado, de los medios y propósitos de observación. Por eso cada segmento de Huacho no termina nunca de establecerse, y no sabemos cómo van a devenir las trayectorias de los cuatro personajes.

\section{¿Hacia una ecología de lo nacional?}

90 La metáfora del laboratorio evocada en la introducción no es arbitraria: obedece al proyecto de dejar abierta las ventanas a nuevas proposiciones en el trabajo de composición de un Chile que se nos escapa y que no fija residencia ${ }^{49}$. Hemos querido permanecer lo más cerca posible de lo que dicen y hacen estas obras, de lo que atestiguan en tanto intervenciones prácticas y simbólicas del mundo. Nos hemos tomado en serio el trabajo de mediación que realizan, reparando ecologías, ensamblando elementos, elaborando proposiciones acerca del territorio físico y social de Chile. Ninguna naturaleza e identidad nacional es posible sin un conjunto de prácticas y 
políticas de narración. Así como no hay "identidad chilena" dada de una vez y para siempre, tampoco existe naturaleza que no tenga adosada un alfabeto de traducción.

91 Si hemos articulado poesía, cine y fotografía, no es para mostrar cómo estos soportes reflejan la naturaleza o identidad de chile, pues esto implicaría re-introducir la oposición entre imaginarios y realidad. "Ecopoemas", "Escrito en el desierto", y Huacho emergen, en última instancia, como instrumentos de experimentación e intervención de eso que denominamos nación, naturaleza y cultura. Cada uno a su manera elabora un caleidoscopio fino de especialidades y materialidades, textos imágenes, valores y prácticas, cuerpos y ritos de un país que se acaba y empieza permanentemente.

La naturaleza de Chile adopta diferentes modos de existencia, ya sea en "Tren al Sur" de los Prisioneros ${ }^{50}$, en la La Araucana de Ercilla, o en el Pabellón de Chile para la Exposición Shanghai 2010. La naturaleza de lo nacional muta en función del filtro escogido, del entramado de prácticas y relaciones que la fabrican. La naturaleza no se limita a la contemplación. Es también una producción política, una confrontación de registros.

93 Se podría sostener que la relación que establecen estos trabajos con la naturaleza cambia en términos de sus grados de disponibilidad. En "Ecopoemas" encontramos una naturaleza amenazada, desprotegida y silenciosa, que requiere de portavoces que vengan a su socorro y a llenarla de significado. Es una posición irónica, sin duda, pero de "salvador" al fin y al cabo. En el caso de "Escrito en el desierto" hay un desplazamiento distinto pero igualmente explícito, que consiste en buscar colectivizar la naturaleza, hacerla expresar una experiencia colectiva, creando un paisaje que implica una interpretación voluntarista y parcial de la historia de Chile.

94 En Huacho, por su parte, encontramos un examen minimalista y aplanado de la naturaleza. No hay voz profética ni gestos refundacionales de un equilibrio planetario perdido. No obstante, es una cámara profundamente moral: plantea el problema de la co-existencia de la multiplicidad. El suyo es un proyecto sin prescripciones ni retóricas de "fin de la historia". Son, más bien, elaboraciones morales que se entraman sin utopías ni banderas.

Parece necesario desnaturalizar la tríada Artes/Naturaleza/Nación y asumir que cada una de sus partes es igualmente problemática y controversial. Tal como lo tratamos de mostrar en estas páginas, la noción de Naturaleza es igualmente impugnable y cuestionable que el concepto de Arte: ambas se fundamentan en debates, mediaciones y demarcaciones. La 'identidad nacional' no puede desvincularse de esos artefactos y dispositivos que la hacen existir. Nosotros mismos, con este texto, participamos inevitablemente de esta historia de configuraciones, de estas políticas de la representación. La "imagen país" no nace separando lo puro de lo contaminado, lo nuestro de lo extranjero, sino de la hibridación de registros. En un momento en que las demandas en torno a la 'reparación ecológica' se multiplican en Chile, se vuelve necesario poner sobre la mesa las diferentes naturalezas en juego y sus formas de legitimación en nuestra sociedad. 


\section{BIBLIOGRAFÍA}

AFEISSA, Hicham-Stéphane (2009), Qu'est-ce que l'écologie, Vrin, coll. Chemins philosophiques, Paris.

ARAYA, Juan Gabriel (2008), “Nicanor Parra. De la Antipoesía a la ecopoiesis”, en Estudios filológicos 43, Facultad de Filosofía y Humanidades de la Universidad Austral de Chile, Valdivia, p. 9-18.

ARAYA, Pedro (2005). « Les écritures poétiques de Raúl Zurita: du ciel au livre », Journée d'étude de l'Atelier méthodologique « Pratiques d'écriture » (EHESS/ ITEM), Photographier l'écrit: épigraphie, reportage, paysage urbain, ENS, Paris. Conferencia no publicada.

AYALA, Matías (2010). Lugar incómodo. Poesía y sociedad en Parra, Lihn, Martínez, Ed. UAH, Santiago. BAZIN, André (1976). Qu'est-ce que le cinéma, Cerf, Paris.

LEFORT, Gérard (2009). « Une vie de Chiliens. Ruraux. « Huacho », ou une journée sans avenir ni électricité » Libération, disponible en https://next.liberation.fr/cinema/2009/05/15/une-vie-dechiliens_558063

DESCOLA, Philippe (2005). Par-delà la nature et culture. Gallimard, Bibliothèque des sciences humaines, Paris.

DEWEY, John (2011). La formation des valeurs, Les empêcheurs de penser en rond / La découverte, Paris.

DEVAISE, Didier (2007). Vie et experimentation. Pierce, James, Dewey, Vrin, Paris.

GEERTZ, Clifford (1989). La interpretación de las culturas. Gedisa, Barcelona.

HUIDOBRO, Vicente (2003). Obra poética. Colección Archivos, ALLCA XX.

INGOLD, Tim (1988). What is an Animal?. Londes, Unwin Hyman. Latour, Bruno (1993).

« Arrachement ou attachement à la nature?», Ecologie Politique, №5.

LATOUR, Bruno (2000). « Morale et technique: la fin des moyens », Revue Réseaux, N¹00, p. 39-58.

LATOUR, Bruno (1999). Politiques de la nature. Comment faire entrer les sciences en démocratie, La Découverte, Paris.

LAPOUJADE, David (1997). William James: empirismes et pragmatisme, Paris, PUF.

MORALES, Leonidas (1992). Conversaciones con Nicanor Parra. Ed. Universitaria, Santiago.

RICHARDS, Nelly (1994). La insubordinación de los signos. (Cambio político, transformaciones culturales y poéticas de la crisis), Editorial Cuarto Propio, Santiago.

ROJAS, Waldo (2001). "Raúl Zurita: “A las puertas de la esquizopóiesis”, en Poesía y cultura poética en Chile, Editorial Universidad de Santiago.

PARRA, Nicanor (2006). Discursos de sobremesa. Ed. Diego Portales, Santiago.

PARRA, Nicanor (1969). Obra Gruesa. Ed. Universitaria, Santiago.

PARRA, Nicanor (1983). Poesía política, Bruguera, Santiago.

PIÑA, Juan Andrés (1990). Conversaciones con la poesía chilena. Pehuén editores, Santiago.

RANCIERE, Jacques (2000) Le partage du sensible: esthétique et politique, La fabrique, Paris. 
RUECKERT, William (1996), "Literature and Ecology: An Experiment in Ecocriticism”, en The Ecocriticism Reader. Landmarks in literary ecology, Ed. Glotfelt, C. y Fromm, H, University of Georgia Press, Athens.

SCHÜTZ, Alfred (1972). Fenomenología del mundo social. Introducción a la sociología comprensiva, Paidós, Buenos Aires.

SCALPELLO, Silvio (2011). « "Huacho", los invisibles de nuestra sociedad » disponible en http:// www.elotrocine.cl/2011/08/28/critica-huacho-2009-los-invisibles-de-nuestra-sociedad/Semaine de la Critique Cannes (2010). « Huacho, un Film d'Alejandro Fernández Almendras », Sophie Dulac Distribution présente Une production Jirafa Films et Charivari Films, Paris.

THRIFT, Nigel (2008), Non-Representational Theory Space, politics, affect. Routledge.

TIRONI, Martín (2012). “Entrevista con Antoine Hennion. Para una sociología pragmática del gusto”, en Disturbios Culturales, ed. José Ossandón y Lucía Vodanovic, Ediciones Diego Portales.

TRACÉS (2012), Écologiques. Enquêtes sur les milieux humains, Nº 22.

ZURITA, Raúl (1982). Anteparaíso. Ed. Asociados, Santiago.Zurita, Raúl (1979). Purgatorio. Ed. Universitaria, Santiago.

ZURITA, Raúl (1994). La Vida Nueva. Ed. Universitaria, Santiago.

URRUTIA, Carolina (2010). “Hacia una política en tránsito. Ficción en el cine chileno (2008-2010)", AISTHESIS No 47, p. 33-44. Notas

\section{NOTAS}

1. Los "Ecopoemas" de Parra fueron primero publicados en forma de plaquette por Gráfica Marginal, en 1982, Valparaíso. Una nueva versión es publicada en el libro Poesía política, de 1983. En el tomo II de las Obras Completas de Parra, se incorporan ambas versiones.

2. "Escrito en el desierto" está incluido en el libro La Vida nueva de 1994. En la p.7, se indica que: "la escritura en el desierto que cierra el libro fue trazada en Atacama, a 56km. al sur de Antofagasta, el año 1993, y tiene un carácter permanente. Su extensión total es de $3 \mathrm{~km}$. Cada letra mide $250 \mathrm{~m}$. y el surco, cavado bajo relieve, tiene $40 \mathrm{~m}$. de ancho y una profundidad de 1.80 m."

3. Huacho (2010) corresponde al primer largometraje del director chileno Alejandro Fernández Almendras (1971). Antes, había dirigido dos cortometrajes, Desde lejos (2006) y Lo que trae la lluvia, (2007). Su último largometraje Sentados frente al fuego lo realiza el 2011. Muchos han identificado su trabajo como parte del "Nuevo Cine Chileno" (con directores como Alicia Scherson, Sebastían Lelio, Matías Bize, entre otros) en contraposición a una generación de los años noventa en Chile, con directores como Andrés Wood, Boris Quercia, etc.

4. Si bien la tradición dualista ha sido cuestionada por diferentes corrientes filosóficas, este artículo se inscribe en la crítica que ha elaborado, y en oposición a la tradición metafísica europea (ver Lapoujade 1997) el pragmatismo americano, con autores como Pierce, James y Dewey.

5. Podemos decir que la perspectiva de este artículo se inscribe en un renovado interés por entender las formas de naturaleza, con autores como Ingold (1988), Latour (1999), Descola (2005), entre otros (para profundizar sobre este punto ver Tracés, 2012) Guardando las diferencias, estos autores comparten una actitud antiesencialista y un deseo por examinar críticamente los procesos de categorización a través del cual se da vida a ciertas entidades y se delimita la frontera entre humano y no-humano, naturaleza y cultura, técnico y social, etc. 
6. De esta gran dicotomía, emergen otros dualismos predominantes como modernidad/tradición, mente/cuerpo, teoría/práctica, ficción/realidad, etc. que también serán puestos en tensión a lo largo de este artículo.

7. Parra (2011), p.177.

8. Es interesante observar cómo, desde una lectura « ecocrítica » como la de Juan Gabriel Araya, en línea con los postulados del ecologismo, este poema de Parra, escrito hace más de veinte años, « vaticina el desastre ecológico en el Río Cruces» (2008, p. 13). Ver de William Rueckert (1996) el artículo "Literature and Ecology: An Experiment in Ecocriticism".

9. Tomaremos una definición deliberadamente amplia del concepto de "mundo de la vida", desarrollado por corrientes fenomenológicas (Schütz, 1972) y sociológicas. Con esta noción queremos hacer referencia a la incuestionabilidad que adoptan ciertas experiencias, circunstancias y objetos en la vida cotidiana de las personas. Nos interesa subrayar particularmente la idea de que las entidades que habitan el mundo están en un estado de indeterminación, y requieren ser explicitadas, puestas a prueba, enunciadas y designadas para hacerlas existir.

10. Utilizamos la noción de "Chile de postal" para referirnos a las imágenes oficiales o largamente socializadas que se utilizan en las tarjetas postales para promocionar el país en el extranjero o simplemente como souvenir.

11. Zurita (1979), p. 10.

12. Remitimos al artículo de Waldo Rojas (2001) para una lectura extensa de Purgatorio. Rojas, recordando la distinción hecha en psicoanálisis entre proceso paranoico y proceso esquizofrénico, aplica esta distinción al campo poético. Mientras la paranoia conserva las estructuras represivas de la sociedad, la esquizofrenia sería de carácter revolucionario por cuanto "capaz de decodificar los territorios codificados y asumir el carácter negativo de la desestructuración" (2001, p. 70).

13. Parra (1969) p. 56-58.

14. Id., p. 64.

15. En sus "discursos", Parra suele propugnar la solución de una "economía mapuche de subsistencia”, que parece afirmarse en el mismo paradigma. Ver, por ejemplo, el Discurso del Bío Bío, con ocasión de la entrega del título de doctor honoris causa por parte de la Universidad de Concepción el año 1996 (ver Parra, 2006).

16. Piña (1990), p. 227.

17. Un ejemplo de este tipo de aproximaciones se puede encontrar en Scalpello, Silvio (2011).

18. Ver por ejemplo Lefort, Gérard (2009)

19. Carola Urrutia (2010), haciendo suya esta distinción entre mundo tradicional y moderno, sostiene que el cine chileno contemporáneo estaría marcado por personajes que padecen el mundo más que habitarlo: "se padece el capitalismo, se padece la transformación vertiginosa y constante de las ciudades".

20. En otras palabras, hemos empleado este discurso con el fin de resituar la discusión entre teorías representacionales y nuestra postura pragmatista explicitada en la introducción. Por teorías representacionales se comprenden aquellos postulados que plantean una separación epistemológica entre realidad y representaciones de esa realidad, desconociendo lo que hay de activo y performativo en ese trabajo de producción y representación (Ver Thrift, 2008)

21. Aclaremos el término mediación utilizado aquí. Con esta noción nos referimos a todos los soportes, instrumentos, cuerpos, textos, etc. que participan en la configuración de una entidad dada y, por ende tienen un carácter ontológico: son capaces de reconfigurar lo que escenifican o transportan (Hennion, 1993). En oposición a la noción de intermediario - entendida como elementos que transportan contenidos ya dados - el concepto de mediación pone énfasis en el rol activo y performativo de los diferentes soportes. Así por ejemplo, la obra música no existe fuera de sus interacciones, del sinnúmero de objetos, actores y procesos (ver Tironi, 2012). 
22. Paradójicamente, este enorme edificio encierra un pequeño bosque que puede verse desde el interior de las salas de investigación. Ese bosque, imagen de lo natural, confinado en esa fortaleza libresca, ¿no muestra al mismo tiempo que es un bosque surgido por y para la biblioteca?

23. Sauriau (1993).

24. Parra (2011), p. 178.

25. Parra (2011), p. 183-184.

26. Araya, (2005). Esta hipótesis es plausible dadas las características de la fotografía: se trata de un día despejado, sin nubes que puedan interrumpir la lectura.

27. Esa indeterminación del discurso se acompaña de la indeterminación sobre el género artístico al que "Escrito en el desierto" pertenecería: ¿poesía, fotografía, Land art?

28. No abordaremos en este artículo las distintas capas de significado implicadas en la imagen del desierto en la obra de Zurita. Por una parte, es innegable su connotación religiosa (bíblica y mesiánica). Rojas (2001), mientras tanto, señala que el Desierto de Atacama en Purgatorio 'no es el de la realidad geográfica ni el de los mapas de Chile. Se trata de una pseudo precisión referencial, un guiño si se quiere: no un referente lingüístico (la extensión territorial concreta y palpable que es un lugar geográfico) sino un 'lugar geométrico' de todos los predicados, una realidad ubicua e inestable, una figura, en suma, que remite a un signo que a su vez expresa algo así como la 'desertitud', al mismo tiempo que deja explayarse el complejo de imágenes significativas contenido en el nombre propio 'Chile'." (2001, p. 69). Sin embargo, es evidente que, en la fotografía, el hecho de que esa figura pase a ser efectivamente el territorio topográfico, cambia también el significado posible del desierto.

29. Piña (1990), p. 227.

30. La noción de descripción densa (thick description) propuesta por Clifford Geertz (1989) propone una concepción semiótica del trabajo etnográfico. En oposición a ciertas visiones positivistas que hablan de la neutralidad, la propuesta de Geertz es reconocer la dimensión interpretativa de la práctica descriptiva, asumiendo que se encuentra inserta en una trama de significados y materialidades igualmente problemática. Desde esta perspectiva, la aspiración a la 'transparencia' o 'naturalismo' descriptivo es reemplazada por la idea del relato.

31. En Le partage du sensible: esthétique et politique (2000) Rancière sugiere que lo político en el cine no se reduce al tema que aborda (a su militancia temática) y que son los medios propios al lenguaje cinematográfico los que pueden devenir políticos en función del régimen de percepción, es decir, la manera en cómo se establece la relación entre lo visible y lo invisible.

32. En una entrevista a un medio francés, Fernández Almendras justifica su opción por actores no-profesionales: "Yo no quería estereotipos de los campesinos. En Chile, los acentos son muy diferentes en función de las clases sociales, de la región de la que se provenga, del trabajo o actividad que se ejerza. Los campesinos en general son representados de una manera caricaturesca por actores que exageran sus acentos y sus gestos. Además, yo quería hacer una película bien física. Una película sobre los trabajadores, de gente en constante movimiento. Para mi un actor profesional no puede resistirse a tener que "interpretar" una acción, ya que todos los gestos del mundo campesino no le son familiares. Cornelio no piensa lo que hace. Cuando corta la madera, él la corta simplemente. Clemira tampoco piensa el hecho de hacer quesos, ella simplemente lo hace tal cual lo ha hecho toda su vida. Esta realidad de la vida cotidiana es algo que no hubiera logrado con actores profesionales. La mayoría de los personajes de esta película viven tal cual lo hacen en sus propias realidades" (Huacho, Dossier de Press, 2010).

33. Sobre esta oposición natural/artificial ver por ejemplo Bazin (1976).

34. Parra (2011), p. 177.

35. Parra (2011), p. 92.

36. Parra (2011), p. 180.

37. Desde su fundación las ciencias sociales han estado atravesadas por el dualismo entre grupos humanos intencionados y, por otro lado, entidades no-humanas sin capacidad de agencia. No 
obstante, recientes trabajos han tratado de reconocer el rol activo de entidades no-humanas (animales, objetos, vegetales) en la composición del mundo social; características que generalmente se imputan a los seres humanos, son ahora reformuladas en el estudio de entidades no humanas.

38. Juan Gabriel Araya (2008) vincula la postura de Parra a la deep ecology desarrollada por el filósofo noruego Arne Naes. La ecología profunda critica los cimientos metafísicos y culturales que se encuentran en la base del desarrollo de Occidente. La ecología debe ser profunda, en el sentido de que debe renovar los cimientos de base de la cultura. Parra se habría acercado al ecologismo en los años 60 en NY. También hay que mencionar la llamada "Propuesta de Daimiel", un manifiesto redactado por el marxista valenciano Josep Vicent Marqués en 1978, en Daimiel, para la Federación del Movimiento Ecologista del Estado Español. Para una visión de conjunto sobre la historia de la ecología, tanto en Estados Unidos como en Europa, ver Afeissa (2009).

39. Parra (2011), p. 178.

40. Parra (2011), p. 179.

41. Piña (1990), p. 227. En un artículo del diario El Mercurio del día 7 junio del 2000, sin embargo, se da cuenta de que el viento y la erosión han borrado casi completamente la frase, siendo solo legible la palabra "miedo". Es interesante que el "borrado" sea la acción de una fuerza - el viento - que no puede revelarse a través de la fotografía. Ver http://diario.elmercurio.com/

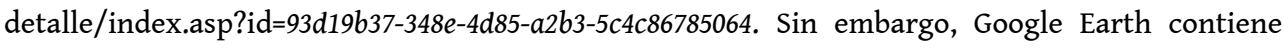
imágenes del 2006 en que la frase es aún completamente legible.

42. Huidobro (2003) p. 1295.

43. Ver Piña (1990), p. 50: "En ese tiempo yo había dado otro paso hacia delante, que era el Ecologismo". El subrayado es nuestro.

44. Ayala (2010), p. 76.

45. Leonidas Morales (1992) menciona que, de acuerdo a su visión ecologista de la poesía, Parra concibe al poeta como "la voz de la tribu, reincorporado a la comunidad". Parra, por su parte, responde que la tarea del poeta en ese contexto es la de ser un "fabricante de pancartas" (p. 119). La poesía, mientras tanto, cumpliría un rol de "autorregulación del espíritu" (p. 129) de la especie humana. Es desde esta "autorregulación" que Parra justifica la producción de textos "antiecológicos".

46. Richards (1994), p.50.

47. Richards (1994), p. 51.

48. Más tarde, el libro Poemas militantes (2000), dedicado al recién electo presidente socialista Ricardo Lagos (2000-2006), volverían a acentuar esa cercanía para algunos polémica.

49. ] William James uno de los precursores del pensamiento pragmático, en el mismosentido señala : "Estamos en relación con la naturaleza de tantas maneras diferentes que ninguna de ellas nos permitiría una aprehensión que la abrace en su totalidad (...). Lo más que podemos esperar de una filosofía, es de no cerrar definitivamente la puerta a ningún interés. Cualesquiera que sean las puertas que cierra, debe dejar otras abiertas para los intereses que deja de lado", en Devaise (2007), p.32. Traducción nuestra.

50. Para ver el video de "Tren al Sur", del disco Corazones Rojos, 1990: https://www.youtube.com/ watch?v=hgAh2MSt1WE\&feature=related. 


\section{RESÚMENES}

A partir del análisis de "Ecopoemas" de Nicanor Parra, "Escrito en el desierto" de Raúl Zurita y Huacho, película de Alejandro Fernández Almendras, el siguiente artículo busca cuestionar la pertinencia de la epistemología dualista en la comprensión de lo natural y cultural de Chile. El objetivo es no tomar la dupla cultura/naturaleza como punto de partida, sino más bien como el punto de llegada de un proceso de composición que involucra múltiples prácticas y estrategias narrativas que serán el objeto de análisis en este documento. Se discutirá así el carácter político de las operaciones que configuran y construyen el universo de estas obras.

À partir de l'analyse des Ecopoemas de Nicanor Parra, Escrito en el desierto de Raúl Zurita et Huacho, de Alejandro Fernández Almendras, il s'agira dans cet article d'interroger la pertinence de la logique dualiste dans la compréhension de l'imaginaire naturel et culturel du Chili. L'objectif est de ne pas prendre le couple nature/culture comme un point de départ, mais comme point d'arrivée d'un processus de composition impliquant des instruments et des pratiques multiples, et qui seront analysés dans ce texte. En accord avec certaines perspectives récentes en sciences sociales, on abordera le caractère politique des opérations qui composent et ordonnent l'univers de ces œuvres.

\section{ÍNDICE}

Mots-clés: nature, dualisme, médiations, Chili, politique, poésie, cinéma

Palabras claves: naturaleza, dualismo, mediaciones, poesía, cine, política, Chile

\section{AUTORES}

\section{MARTÍN TIRONI}

Doctorante en el Centre de Sociologie de l'innovation, CSI, Ecole des Mines de Paris

\section{CHRISTIAN ANWANDTER}

Doctorante en Théorie de la littérature et sciences humaines - LAC, Université Paris VII 